\title{
Action of Poly-L-malic Acid on Various Proteolytic Enzymes
}

\author{
By Kin'ichi Matsushima \\ Department of Agricultural Chemistry, Faculty of Agriculture, \\ Mie University, Tsu \\ Received May 4, 1970
}

Recent studies in this laboratory have demonstrated that a strain of Penicillium cyclopium produces a substance capable of inactivating the acid protease of the mold, " and the substance has been found to be poly-Lmalic acid (PMA). ${ }^{21}$ Further experiments have revealed that the role of PMA in the inactivation of the acid protease is an acceleration of degradation, or auto-digestion, of the enzyme. $^{31}$ The present communication deals with the action of PMA on various proteolytic enzymes other than the above acid protease.

Pepsin (2X crystallized, Worthington Biochem. Corp.), trypsin (crystalline, Mochida Pharmaceutical Co.), papain (2X crystallized, Worthington Biochem. Corp.), the alkaline protease from Bacillus subtilis var. amylosacchariticus Fukumoto (crystalline, furnished by Dr. Tsuru of the Faculty of Science, Osaka City University), and the acid protease $B$ from Aspergillus niger var. macrosporus (crystalline, furnished by Dr. Koaze of the Research Laboratories, Meiji Seika Ltd.) were used in this experiment. PMA was isolated from an aqueous extract of wheat bran culture of $P$. cyclopium according to the method reported previously." Proteolytic activity was deter-

1) K. Shimada and K. Matsushima, Nippon Nogeikagaku Kaishi, 41, 454 (1964).

2) K. Shimada, K. Matsushima, J. Fukumoto and T. Yamamoto, Biochem. Biophys. Res. Communs, 35, 619 (1969).

3) K. Matsushima and K. Shimada, Agr. Biol. Chem., 34, 47 (1970).

4) K. Shimada and K. Matsushima, ibid., 33, 544 (1969). mined by measuring the tyrosine liberated from a casein solution using the Folin-Ciocalteu's reagent and the activity was expressed as optical density increment of the incubated solution over that of the corresponding blanks. Protein was determined by the method of Lowry et al. ${ }^{5}$

Precipitation by PMA of the proteolytic enzymes was studied as a function of $\mathrm{pH}$ and the per cent of enzyme precipitation plotted against $\mathrm{pH}$ is shown in Fig. 1. The results indicate that PMA allowed to precipitate all the proteolytic enzymes tested with the exception of pepsin which has been shown not to be inactivated, at $\mathrm{pH} 3.0$, by PMA. ${ }^{6}$ Precipitation occurred maximally at an acid $\mathrm{pH}$ but the $\mathrm{pH}$ region for precipitation differed with each enzyme. Table $I$ is the result of experiments on the effect of incubation of the mixture of enzyme and PMA on the activity of the proteolytic enzymes. Trypsin, which formed precipitate over the $\mathrm{pH}$ range employed, reduced its activity when the incubation was carried out at either $\mathrm{pH} 3.0$ or $\mathrm{pH}$ 7.5. The activity of chymotrypsin was likewise destroyed on incubation with PMA at $\mathrm{pH}$ 7.0 as well as at $\mathrm{pH} 3.0$, although it formed no precipitate in solutions of neutrality. This seems to be indication of combination even though no precipitate forms. Papain suffered no inactivation by PMA, although it reacted with PMA to form precipitate over the $\mathrm{pH}$

5) O. H. Lowry, N. J. Rosebrough, A. L. Farr and R. J. Randall, J. Biol. Chem., 193, 265 (1951).

6) K. Shimada and K. Matsushima, Agr. Biol. Chem., 33, 549 (1969). 


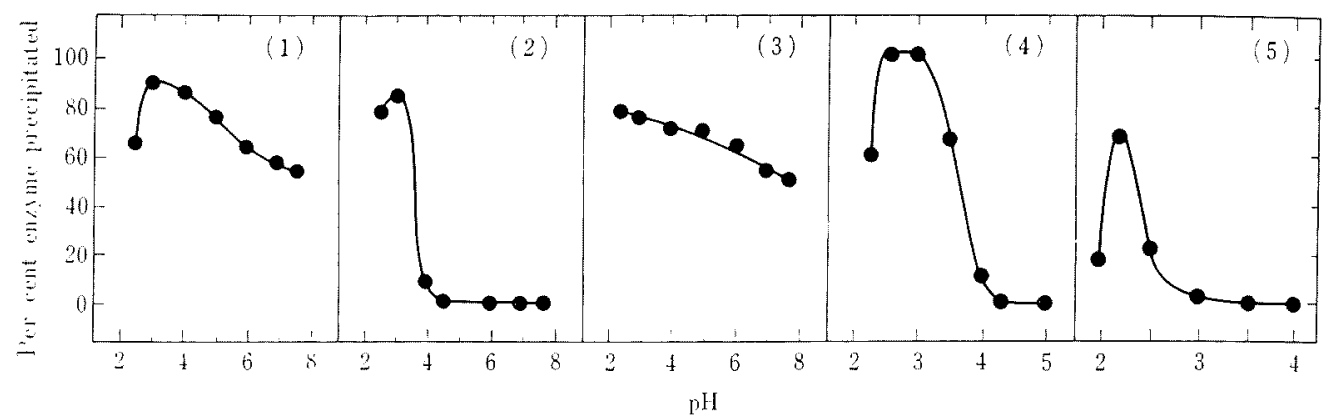

FIG. 1. Precipitation of Proteolytic Enzymes with PMA as a Function of $\mathrm{pH}$.

Buffer solutions used were $5 \mathrm{~mm}$ sodium citrate-hydrochloric acid ( $\mathrm{pH} 2.0$ ) and $5 \mathrm{mM}$ sodium phosphate-citric acid $(\mathrm{pH} 2.2 \sim 8.0$ ). Four hundred milligrams of enzyme was mixed with $80 \mu \mathrm{g}$ of PMA in $2 \mathrm{ml}$ of buffer solution and the precipitates formed were collected by centrifugation. The operations were carried out at $0 \sim 2^{\circ} \mathrm{C}$. The final $\mathrm{pH}$ was checked on the supernatant with glass electrode. The precipitates were dissolved in $2 \mathrm{ml}$ of $0.2 \mathrm{M}$ sodium carbonate and portions of this solution were analyzed for the protein concentration. (1); trypsin, (2); chymotrypsin, (3); papain, (4); alkaline protease from $B$. subtilis var. amylosacchariticus, (5); acid protease B from A. niger var. macrosporus.

TABLE I. EFFECT OF PMA ON THE ACTIVITy OF VARIOUS PROTEOLYTIC ENZYMES

\begin{tabular}{|c|c|c|}
\hline Proteolytic enzymes & Preincubation & $\begin{array}{l}\text { Per cent } \\
\text { inhibition }\end{array}$ \\
\hline \multirow[t]{2}{*}{ Trypsin } & $\mathrm{pH} 3.0,40^{\circ}$ & 58.5 \\
\hline & $\mathrm{pH} 7.5,25^{\circ}$ & 77.4 \\
\hline \multirow[t]{2}{*}{ Chymotrypsin } & $\mathrm{pH} 3.0,40^{\circ}$ & 77.0 \\
\hline & $\mathrm{pH} 7.0$, & 46.9 \\
\hline \multirow[t]{2}{*}{ Papain } & $\mathrm{pH} 4.0$, " & 0 \\
\hline & $\mathrm{pH} \mathrm{7.0,"}$ & 0 \\
\hline \multirow{2}{*}{$\begin{array}{l}\text { Alkaline protease from } \\
B \text {. subtilis var. amylosac- } \\
\text { chariticus }\end{array}$} & $\mathrm{pH} 4.0,25^{\circ}$ & 95.5 \\
\hline & $\mathrm{pH} 5.0, " \prime$ & 9.7 \\
\hline \multirow{4}{*}{$\begin{array}{l}\text { Acid protease B from A.niger } \\
\text { var. macrosporus } \\
\text { Pepsin }\end{array}$} & $\mathrm{pH} 2.2,40^{\circ}$ & 77.3 \\
\hline & $\mathrm{pH} 3.0, " 1$ & 8.6 \\
\hline & $\mathrm{pH} 1.0,28^{\circ}$ & 0 \\
\hline & $\mathrm{pH} 1.5, "$ & 2.2 \\
\hline
\end{tabular}

Enzyme $(0.2 \mathrm{mg}$ per $\mathrm{ml})$ was preincubated with PMA (40 $\mu \mathrm{g}$ per $\mathrm{ml}$ ) in $5 \mathrm{~mm}$ sodium phosphate-citric acid buffer ( $\mathrm{pH} 2.2 \sim 7.5$ ) or in $10 \mathrm{~mm}$ sodium citrate$\mathrm{HCl}$ buffer $(\mathrm{pH} 1.0 \sim 1.5)$ under the conditions presented in the Table. After 30 min' preincubation, portions of the mixture were added to casein solutiom for the determination of enzyme activity. Caseinolysis was conducted at $\mathrm{pH} 7.5,9.0,5.0,10.0,3.0$ and 1.8 for trypsin, chymotrypsin, papain, alkaline protease from $B$. subtilis var. amylosacchariticus, acid protease $B$ from A. niger var. macrosporus and pepsin, respectively. The per cent inhibition was calculated as follows: $a / b \times$ 100 , wherein $a$ was obtained by subtraction of the absorbance with PMA from the absorbance without PMA and $b$ was the absorbance without PMA. range employed. This seemed to indicate that papain combined with PMA to form a water insoluble complex remained active

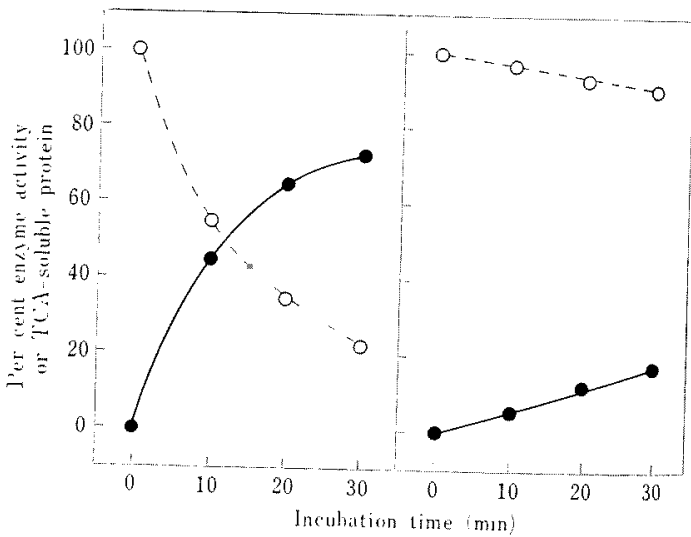

FIG. 2. Change of Activity and Solubility in TCA of Trypsin during the Course of Incubation with PMA at $\mathrm{pH} 7.5$.

Trypsin $(0.2 \mathrm{mg}$ per $\mathrm{ml})$ was incubated with PMA $(25 \mu \mathrm{g}$ per $\mathrm{ml}$ ) in $5 \mathrm{~mm}$ sodium phosphatecitric acid buffer, $\mathrm{pH} 7.5$, at $25^{\circ} \mathrm{C}$. At intervals, portions of the reaction mixture were withdrawn and analyzed for the activity. Other portions were mixed with TCA to a final concn. of $0.2 \mathrm{M}$, centrifuged, and the supernatant solution was analyzed for protein. O---O; activity of enzyme, -- TCA-soluble protein, left; trypsin+PMA, right; enzyme alone. 


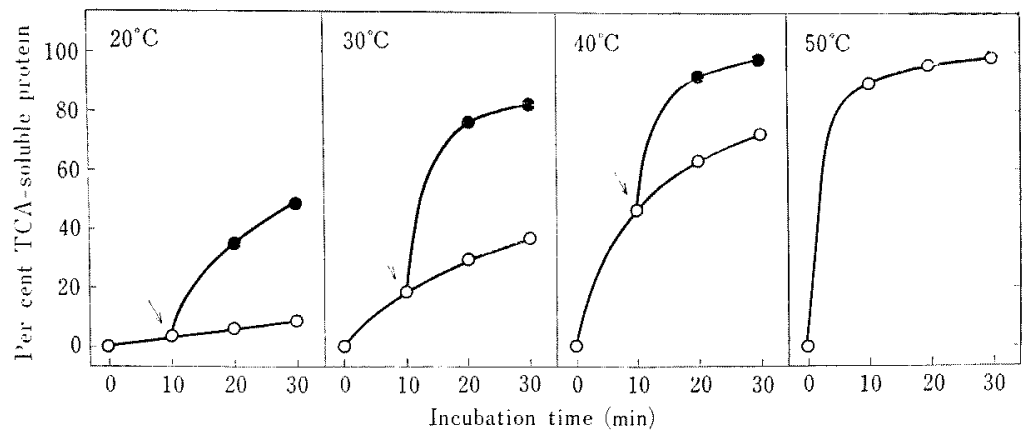

FIG. 3. Accelerating Effect of PMA on the Modification of Trypsin.

The standard system (O) contained $0.2 \mathrm{mg}$ trypsin per $\mathrm{ml}$ in $5 \mathrm{mM}$ sodium phosphatecitric acid buffer, $\mathrm{pH} 7.5$. PMA $(40 \mu \mathrm{g}$ per $\mathrm{ml}$ ) was added to the system where indicated by arrows. ( ) ; the systems containing PMA. The modification of trypsin was estimated in terms of increase in the amount of TCA-soluble protein which was determined as noted in Fig. 2.

during the incubation and the combination was readily broken in a solution containing foreign protein (substrate milk casein) as reported on the acid protease from P. cyclopium. ${ }^{3}$ The effect of PMA on the alkaline protease from $B$. subtilis var. amylosacchariticus was studied at $\mathrm{pHs}$ above 4.0 because of its instability at $\mathrm{pH} 3.0$ where maximum precipitation occurred. Almost complete inactivation of the alkaline protease occurred by incubation with PMA at $\mathrm{pH} 4.0$ in spite of a tendency of forming precipitate at this $\mathrm{pH}$. It seems worth noticing that the acid protease $\mathrm{B}$ from A. niger var. macrosporus, which was previously classified as being "inhibitor-resistant" protease from the result of experiments wherein enzyme and inhibitor (PMA) were allowed to react at $\mathrm{pH} 3.0,{ }^{6 \prime}$ did not form precipitate at $\mathrm{pH} 3.0$, but did precipitate maximally at $\mathrm{pH} 2.2$, and that subsequent incubation of the mixture at this $\mathrm{pH}$ resulted in significant loss of its activity. This was also observed with the acid proteases of other molds, such as $A$. wentii, A. saitoi and Paecilomyces varioti, which were previously shown to be of "inhibitor-resistant." ${ }^{6}$ ) On the basis of this finding, I wish to cancel the discrimination between the "inhibitor-sensitive" and the "inhibitor-resistant" proteases among the acid proteases of various molds. ${ }^{6}$ Pepsin suffered no inactivation by PMA either at $\mathrm{pH} 1.0$ or at $\mathrm{pH} 1.5$.

Change of activity and solubility in TGA of the proteolytic enzymes during incubation with PMA were then studied. It was found that the inactivation by PMA of trypsin at $\mathrm{pH} 7.5$, of chymotrypsin at $\mathrm{pH} 7.0$, of the

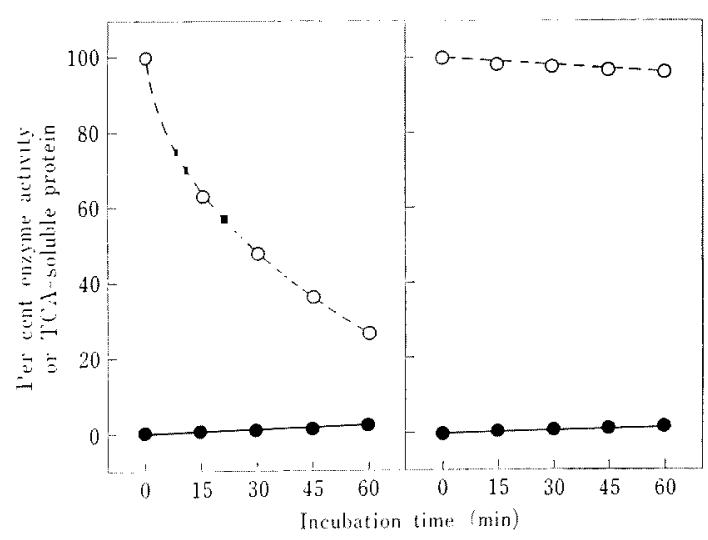

FIG. 4. Change of Activity and Solubility in TCA of Trypsin during the Course of Incubation with PMA at $\mathrm{pH} 3.0$.

The experimental conditions and symbols are the same as presented in Fig. 2 except incubation was carried out at $\mathrm{pH} 3.0$ and at $40^{\circ} \mathrm{C}$. Left; trypsin +PMA, right; enzyme alone. 
acid protease $\mathrm{B}$ from $A$. niger var. macrosporus at $\mathrm{pH} 2.2$, and of the alkaline protease from $B$. subtilis var. amylosacchariticus at $\mathrm{pH} 4.0$ was accompanied by modification of enzyme so that less was precipitable with trichloroacetic acid (TCA) and that PMA operated in a catalytic fashion so that the rate of the modification was accelerated even under conditions where the enzyme alone remained fairly stable. Typical results with trypsin are presented in Fig. 2 and Fig. 3. In these respects, the mode of action of PMA on these enzymes was identical with that of PMA on the acid protease from $P$. cyclopium reported previously. ${ }^{31}$ On the contrary, the inactivation by PMA of trypsin and chymotrypsin that oc- cured at $\mathrm{pH} 3.0$ was found to be accompanied by little increase in the amount of TCAsoluble material. In Fig. 4 results obtained with trypsin are presented. These results suggested that the inactivation by PMA of trypsin and chymotrypsin at $\mathrm{pH} 3.0$ involved mechanisms distinctly different from that described above, and further experimentation is necessary to explain fully this interesting observation.

Acknowledgements. I thank Dr. D. Tsuru of the Faculty of Science, Osaka City University and Dr. Y. Koaze of the Research Laboratories, Meiji Seika Ltd. for their kind supplies of purified proteases from microorganisms. 